\title{
Jewish childhood
}

\section{Growing up in New Zealand}

\section{ANN BEAGLEHOLE}

'What Church do you go to?', one of the women interviewed in our study about the lives of Jews in New Zealand was asked when she first started school in Hawera during the mid 1950s. She was eight and had recently come with her family from South Africa to live in New Zealand. When she replied that she was Jewish, the questioner said: 'Yes, but what Jewish, Presbyterian Jewish or Anglican Jewish?'

Such questions illustrate how little many non-Jewish New Zealanders in earlier decades knew about Jewish people. Living with this ignorance was (and perhaps still is) one of the significant characteristics of a New Zealand Jewish childhood.

In South Africa the woman being quoted had lived in a closely-knit, though small by South African standards, Jewish community where 'everyone' was Jewish and therefore Jewishness had seemed 'normal'. Her earliest memory of being Jewish in New Zealand is that here nobody else was - an upsetting notion for her as a young girl. Eventually she was reassured by her mother's list of other people who were Jewish, though not unfortunately living in Hawera.

The discussion which follows focuses on childhood. It is part of a larger study about the lives of New Zealand Jews and is based on interviews with diverse people of Jewish background: young and old, religious and secular Jews, converts and part-Jews, former refugees, recent immigrants from South Africa and people whose families have lived in New Zealand since colonial times.

A certain kind of Jewish identity and community life has developed in New Zealand in response to the particular circumstances of Jewish life here. These are New Zealand's isolation from the larger centres of Jewish life, the fact that Jews have always been a small minority group, and the low level of anti-Semitism and the high level of acceptance that Jews have received in New Zealand. The positive side of the ignorance about Jews has

'Whatever happened to me as a Pole was terrible and I have tried to forget my childhood', one man told us. A number of those in the study grew up in pre-war Poland, Czechoslovakia or Austria and their references to antiSemitism even before the advent of the Nazis provide a striking contrast to life in New Zealand. The experiences of those who grew up in Leeds, or New York or Capetown or elsewhere in sizeable, close-knit, Jewish communities also highlight the peculiar features of the New Zealand experience. Jews have never been numerous here. (The number of Jews who state they are Jewish in the Census has stayed around 3000 or $0.1 \%$ of the population.) The small number of Jews is in part due to immigration restrictions but also to the fact that the New Zealand Jewish community has had over the years. a strongly migratory character. Jews have come and other Jews have gone. If everyone who had come had stayed, the Jewish community would have become a sizeable one in spite of the high rate of intermarriage and general assimilation. But only certain types of Jews have been willing to leave major centres of Jewish population and come to a distant, isolated community and only certain types have been willing to stay. The intensity of Jewish life and a strong sense of community is not entirely dependent on size but does depend on Jews living in close proximity. This also has not occurred in New Zealand. A rather tepid, diluted version of Jewishness has developed and is maintained in this country.

Jewish childhood in the years between the 1920 s and the 1980 s is examined from two separate but closely linked points of view: the first, the Jewish world of the children - what was that like? - and second, the relationship of this world to the outside, to the non-Jewish world.

The discussion is confined to the experiences of those in the study who grew up in families that tried to maintain some of the traditions of Jewish life whether religious, cultural or Zionist. Interviewees who grew up in part-Jewish families (whose self identification was often more complex and who sometimes felt as outcasts from the Jewish community) or in families in which the parents had chosen not to maintain any kind of Jewish life for whatever reason are not the concern here. The experiences of children of Holocaust survivors also warrant separate treatment and will not be discussed in this article.

\section{JEWISH WORLD}

The people in the study were asked about the religious observances in their families, about secular Jewish practices - what sort of food was cooked, was Yiddish spoken, were there books about Jewish subjects in the house, and they were questioned about family relationships. Standing out from the interviews are the recollections of family warmth and unity set against the restrictions, the pressures, the conflicts and the sense of guilt imposed on children in the struggle to prevent assimilation. A picture emerges of children confused by familial expectations to keep the Jewish traditions and at the 


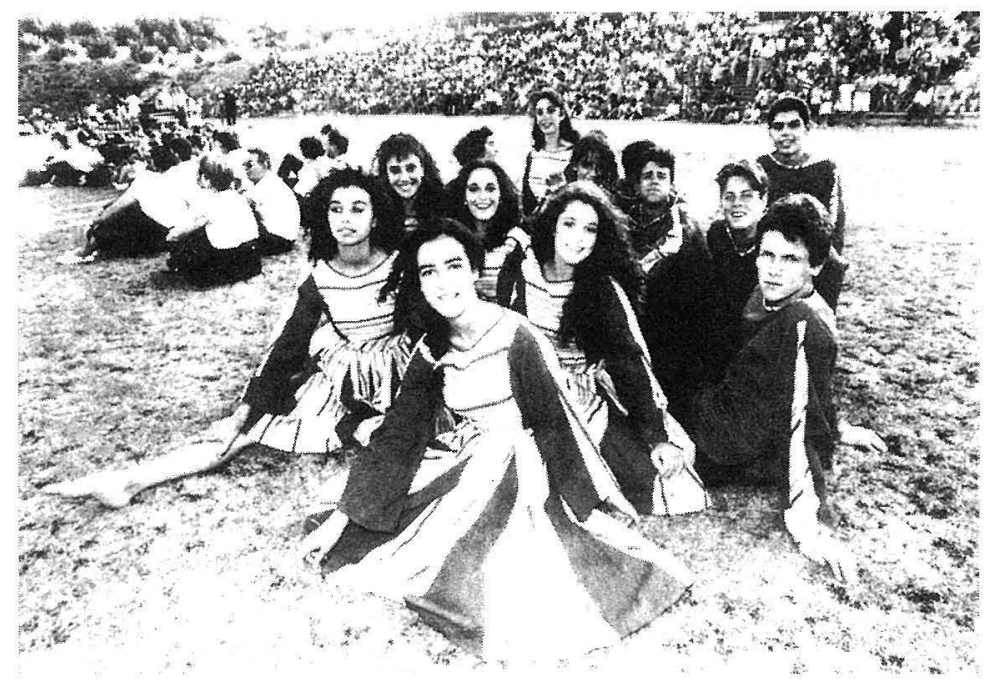

His school orchestra practised on Friday nights and although his parents very much wanted him to be in the orchestra, they still would not let him go to practices on Erev Shabbat.

Another man who grew up in Wellington in the fifties (his parents were also of Eastern European origin) had similar recollections:

My father never worked on Shabbos (Sabbath). We always went to shul (synagogue) and we had a strictly kosher (according to the dietary rules) home. My father never ate out anywhere. We had as religious an upbringing as possible given the facilities in New Zealand.

Activities related to support-
Jewish children in Israel

same time to participate fully in the non-Jewish world. Bewildered by contradictory injunctions to be proud of being Jewish yet avoid emphasizing it too much, to shun close relationships with non-Jews yet not set themselves apart, the people in the study can be seen juggling uneasily the disparate obligations of their separate worlds.

There was much variation in the extent of religious observance practised by families. Children had grown up with at least some of the following: circumcision, observance of some Jewish festivals, occasional or regular observance of Friday nights (lighting candles, prayers), occasional or regular synagogue on Saturday, some observance of the dietary rules (if only an avoidance of pork and shellfish), attendance at weekly Hebrew school and Jewish youth group. and celebration of barmitzvah and batmitzvah (ceremonies at the age of thirteen to mark the passage from youth to adulthood). Inevitably most of the families had made compromises. They would keep this custom, but not that; they would go to the synagogue for festivals but not every week. They would drive on the Sabbath, but not allow their children to play sport on that day.

A few of the interviewees came from Orthodox families that were less willing to make compromises and more committed to providing children with an unstintingly Jewish upbringing. One man who grew up in Wellington during the twenties and thirties and later emigrated to Melbourne (his father came from Lithuania and his mother from Poland) recalled:

The family kept strictly kosher. Eating outside the home was forbidden. All the festivals were kept. There were a lot of restrictions on everything we did - who our friends were (they had to be Jewish), what we ate. what we did, especially on Saturdays. ing Palestine/Israel were also a feature of Jewish family life. Bonds for Israel were framed and put on living room walls; blue boxes (for collecting money for Israel) sat on shelves. Planning Aliyah (to go to Israel permanently), or just for a trip, or simply dreaming about going one day were also part of growing up Jewish. Recalled one interviewee:

It was a really peaceful home on Shabbat (Sabbath). No cooking was done, everything was cooked the day before and you would get up in the morning and there would be this lovely smell in the house... it was always warm because the oven was left on... and there was an atmosphere of being contained (in a warm family). But it was more than that. It was a day when you really did rest and you had nice food and no one had to cook on that day. It was a special feeling, you know.

Although this man is talking about an Orthodox childhood in Bombay, not New Zealand, his words convey what others in the study meant when they spoke of the positive characteristics of Jewish childhood in Timaru or Wellington or elsewhere - of warmth, togetherness, on occasions such as Friday nights or Pesach (Passover) when families, especially extended families, assembled and celebrated being Jewish together.

Others were less inclined to focus on family warmth and togetherness than on the claustrophobic aspects of close family living and above all on the restrictions and pressures that had dominated their lives as children.

Sporting activities were prevented or disrupted by the Jewish Sabbath. If children were lucky or had cooperative parents, synagogue and sport could both sometimes be fitted in: 'Shul first and if you took your gear with you. you could go off to soccer afterwards', recalled one interviewee. Prohibitions on what could or could not be eaten also put children at odds with themselves or with their parents.

Restrictions on non-Jewish friendships caused the 
most strife especially during the teenage years. For many in the study the Jewish world began to feel increasingly narrow at adolescence. As an interviewee growing up in Auckland during the sixties and seventies who had been confined to socializing mainly with other Jews, recalled: 'I knew everybody, everybody was my cousin. There was absolutely no scope socially.'

As one would expect, children's response to parental impositions varied greatly, even in the same family. One interviewee said that while he took for granted the restrictions of his upbringing, his sister did not. She demanded to go to dances on Saturdays, had non-Jewish friends and 'got away with it'. The dietary restrictions were simply ignored by some children, especially if they could see how readily older people made compromises about Jewish observances. Other children were obedient to the dictates of their parents and suffered the embarrassment of taking matzoh (unleavened bread), to school during Pesach, or having to avoid foods such as cheerios at birthday parties.

In some families, it was the children who led the way in matters of Jewish practice. It was they who insisted on more observance than their parents were comfortable with and would, for example, accuse family members of hypocrisy when they drove to shul on the Sabbath or kept kashrut at home yet would eat non-kosher food at a neighbour's. Nor was an exclusively Jewish social life always imposed by the adults. The young people themselves wanted to find Jewish spouses and were wary of pursuing close relationships with non-Jews as such relationships did not have a future. But more often than not, where there was conflict between parents and children, it was the children who wanted greater freedom to participate in the non-Jewish world than their parents, fearing assimilation, would allow.

There were various messages they received in such cases. It could be: 'You'll hurt your mother or your father if you eat mince pies at school or don't have a barmitzvah'. Guilt operated particularly strongly in families of former refugees. Children were under pressure to avoid hurting parents who had been 'through so much'. They felt they would 'break their mother's or father's heart' or 'kill' their parents if they did certain things, play rugby on Saturday, for example. Marrying 'out' was the worst blow they could inflict.

Conformity was also promoted by messages such as: 'You should be proud of being Jewish'. The message would continue as follows: 'Even if you are a small minority, even of you are the only Jew in the town or in your school, you must always keep your Jewishness'.

Such tactics were effective in some families and there were children who came to believe that the preservation of Judaism was their personal responsibility. In other families 'ramming religion too much down children's throats' was problematic and likely to be challenged on the grounds that parents were expecting 'higher' or different standards of Jewish observance from their children than they were prepared to practise themselves.

The parents' task of inculcating Jewishness was assisted by two institutions established by the Jewish community to foster Jewish education. Most parents with some interest in maintaining their children's Jewishness sent their offspring to Hebrew School. Without exception, interviewees had negative recollections of it. It had been 'very boring' and 'a complete waste of time'. Going to Hebrew School had meant that the children had less free time than their peers at weekends and most had resented this.

A picture of futile struggle to maintain an effective level of Jewish education is portrayed in the Jewish community newspaper throughout the period covered in this study. Commentators tend to blame the parents who are accused of regarding the Hebrew School as a means of being relieved of their children for a few hours on a Sunday morning and of failing to support their children's Jewish education to anywhere near the same level as their secular education. Additionally parents are at fault because:

the values taught at the school are in contradiction, even in conflict, with what is practised at home... it is small wonder that the great majority of children grow up with a degree of Jewish knowledge that barely lifts them above the level of religious illiterates.

- Editorial, New Zealand Jewish Chronicle, February 1978

The youth groups were more effective inculcators of Jewish identity than the Hebrew School. Because of their very success, they had a significant part to play in the creation of those conflicts and pressures which dominated young people's lives.

The Zionist socialist youth group Habonim (the builders) began in the 1940s. From the 1960s, an alternative youth group B'nai Akiva (sons of Rabbi Akivah), with a religious and Zionist rather than a socialist orientation, was also available for young people. The youth groups had weekly Sunday meetings during the year and camps in the summer when children from all parts of New Zealand gathered to learn Hebrew, Israeli songs and dances, Jewish history, and about life in Israel, especially on kibbutz.

The people in the study stressed the importance of the close friendships with other Jewish children made possible through the youth groups. Such friendships had lessened the isolation as Jews that many recalled had been the chief characteristic of their childhood.

However, the message of the youth leaders - that young people, if they wished to lead an adequate Jewish life, had no choice but to leave New Zealand and settle in Israel - created problems for parents and children. Many parents who sent their children to the youth group for social and educational purposes were afraid of the Zionist indoctrination. The difficulties for young people arose out of the discrepancy between what the youth group told them was the right way for a Jew to live, and what they 
observed their parents doing. Even more problematic was that while young people's Jewish identity was strengthened through the youth groups, there existed few outlets for the expression of this outside the group. It is ironic that many came to see emigration, not participation in the life of the New Zealand Jewish community, as the only possible way to retain that strengthened Jewish identity.

\section{JEWISH CHILDREN IN A NON-JEWISH WORLD}

What kind of relationship was there between families struggling to preserve a Jewish life and transmit Jewish traditions to the next generation and the non-Jewish world?

Being Jewish in a non-Jewish environment meant living with conflicts and compromises. Earning a living in the retail business, for example, as a number of the families in the study did, meant keeping your shop open on Friday nights and Saturday mornings which interfered with the celebration of the Sabbath. The many different children's activities scheduled for Saturdays also disrupted that day. Jewish life had to be fitted in as best it could amidst numerous conflicting obligations in the wider society.

For many interviewees, there were two separate worlds: the non-Jewish one of school which extended into some of the weekend through such activities as sport, and the Jewish world of family, synagogue, Hebrew School and youth group. The people in the study usually had two sets of friends - Jewish and non-Jewish. The two worlds did not generally mix. When they did occasionally come together at children's birthday parties, for example, it was awkward and difficult because the guests did not know each other.

When the people in the study spoke of living in separate worlds, they also commented on how little the non-Jewish world knew about Jews. The ignorance and lack of acknowledgement of difference increased the feelings of isolation of Jewish children referred to earlier. The perception that no one knew anything about what mattered to you as a Jewish child was felt most acutely by those who grew up in rural areas and small towns. An interviewee who grew up in a small South Island town during the fifties and sixties recalled meeting people who would say to her: 'Oh, you're the first Jew I've ever met, I didn't know there were any Jews still. Another interviewee from a small North Island town where hers was the only Jewish family used to be asked what a Jew was by the children at her school: 'You look exactly the same as us, you look exactly the same', they would say with surprise.

Children's feeling of isolation and perception of living in separate worlds, one of which was ignorant about the other, was highlighted at times of Christian or Jewish festivals. Acknowledgement of these (even the major ones) or Jewish beliefs (except for not eating pork) was rarely encountered. It was painful to have what mattered to Jews always ignored. Non-Jews had no conception that there may exist people who did not have Christmas, for example, or that there may be different festivals that others with different backgrounds may be celebrating.

Children responded to this in different ways. One strategy, aimed at avoiding the curiosity and the pity of other children, was simply to pretend that your family did have Christmas and that you received Christmas presents like everybody else. One person recalled 'sheltering' her younger brother from the hard truth that there was no Christmas for Jewish families. She saved up her pocket money and bought her brother colouring books and filled his stockings. Her parents humoured her for a while, but when she was older, she and her brother were both expected to adjust to the replacement of Christmas by Chanukah (a Jewish festival which occurs around the same time).

It is significant that a number in the study said that they first became aware of being Jewish at Christmas time. The knowledge really 'clicked' into place then, one woman said. Being Jewish meant doing without Christmas.

Some parents wanted the children to have the best of both worlds. Their children were given Christmas presents on Christmas Day and told they were for Chanukah. It is hard to know how common it was for Jewish families to merge Jewish and Christian festivals so as to please the children. Certainly families behaving in this way were likely to encounter some community disapproval. A New Zealand Jewish Chronicle editorial, (December 1970) had this to say:

It seems to us that in recent years the celebration of Chanukah has become such that it is almost as though we do not know what we are celebrating.....perhaps this is because this holiday comes at a time of the year when non-Jews are celebrating, with parties and gifts, a festival of their own - and we don't like to be different. This coincidence has led to a most peculiar growth and welter in the customs observed by some Jews - that of the Chanukah gift, brought by the Chanukah man and sometimes even hanging from the Chanukah Tree. The traditional form of gift seems to be unheard of by the children (and some parents) and some youngsters even insist on a lighted tree and valuable presents. How can parents who value any sort of Jewish tradition not disillusion their offspring? How can they permit themselves to ape non-Jewish customs, indiscriminately, particularly those which pertain to the birth of Yehoshua of Nazareth, about whose name stories and beliefs accumulated, leading to the founding of Christianity. After all, no matter how religious or nonreligious any Jew might be, one of the common bonds between all is the belief that this Nazarene was not a supreme being.

In discussing relationships with non-Jews, interviewees were asked whether they had felt different, or to some extent outsiders, during their childhood, and if so, how they had coped with this. It is difficult to tell how perceptions changed from the assumption (that young children make) that everybody does the same things in their family that they do in theirs, to the realization, held by many in 


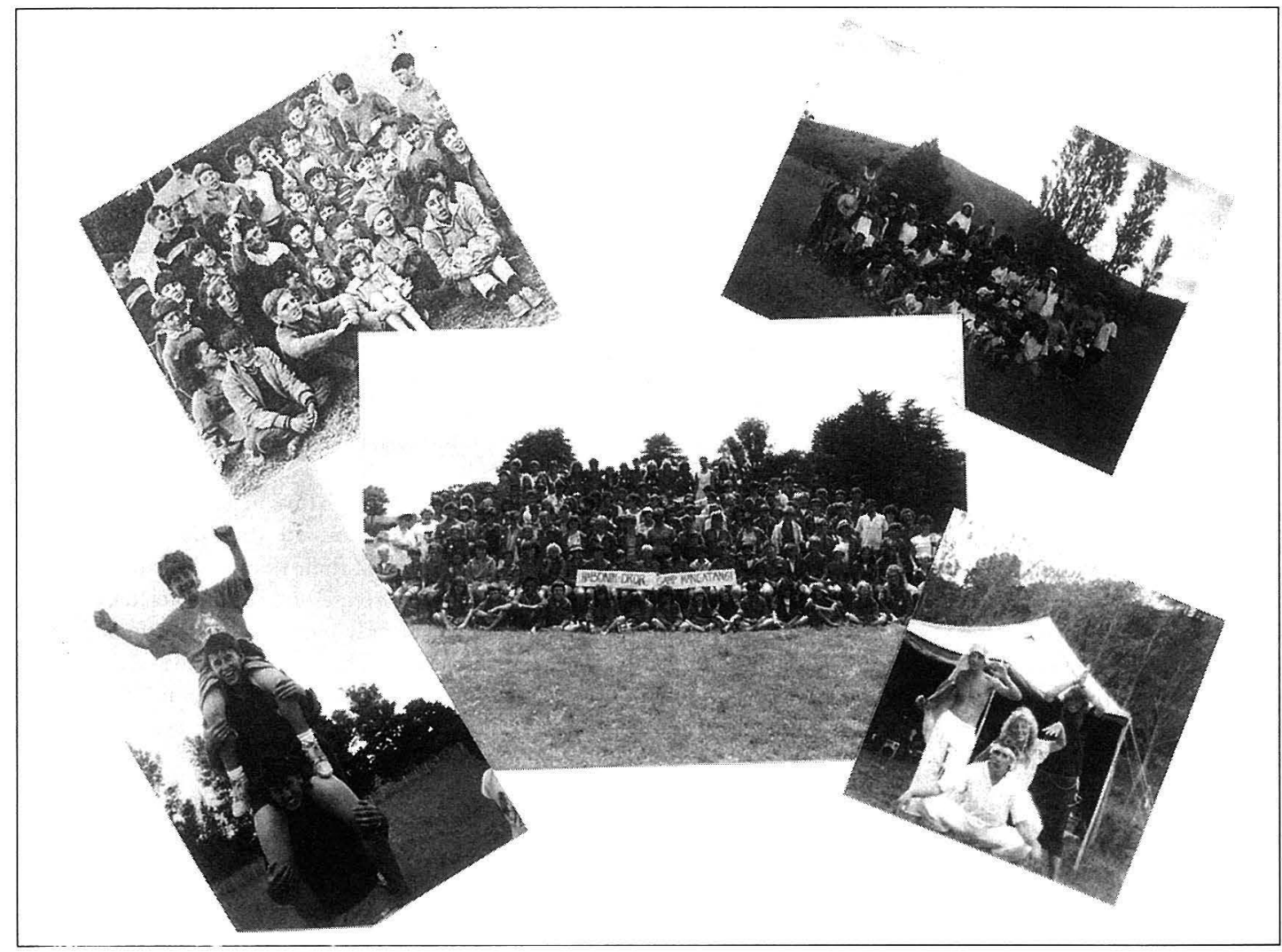

A composite of scenes of Jewish children in New Zealand. New Zealand Jewish Chronicle.

the study later on, that being Jewish was somehow not quite a normal part of life. Certainly by adolescence Jewishness was no longer simply taken for granted. One interviewee, for example, began by describing his traditional Jewish childhood as 'pretty much the same as any kid growing up in New Zealand.' By the time of his Barmitzvah he knew he was different. At this stage he began to wear a kippa (skull cap) and to turn down invitations to go out on Friday nights and Saturdays. But what happened in between? The changing perceptions between early childhood and adolescence have not been recorded in this study.

A few interviewees had looked on being Jewish as 'special' and had enjoyed being different. One woman spoke with some embarrassment of having felt not only special but better and even superior, because 'she had extra things' that her non-Jewish friends did not have: matzoh, 'two thousand years of Jewish heritage' and Israel.

There were also a group of interviewees who had felt different and had not liked it. As one man who grew up in Wellington in the fifties, (now living in Israel) recalled: 'From a very young age I was made to feel extraordinarily
Jewish and extraordinarily different. I can recall being dragged off to shul on Shabbat and of course Sunday was a great day also having to go off to Hebrew School as well. At school one was immediately separated from the rest of one's class. I couldn't go to scripture lessons - I had to stay outside. All the other kids went to Scouts and I didn't have a Scout troop. I couldn't play cricket on a Saturday morning, I couldn't play rugby ...'

\section{SCHOOL}

Negative feelings about being different were revealed when some people in the study spoke of school. It was hard to be the only Jewish child at a primary school. At high school, it was more likely that there would be a small group of Jewish children which made life easier. Recollections of what it was like to be Jewish at school centred round the occasional anti-Semitic incident (people also spoke about the lack of anti-Semitism and on the support of individual teachers); recollections also focused on Christian prayers and religious instruction at school, and on the pressure from families to succeed in the school system.

Regarding the pressure to succeed, one interviewee with a refugee background (now living in Israel) recalled:

As a Jew, I had to be first in the class and heaven help me if I ever brought home a report card when I was second in class because I wouldn't hear the end of it until I brought 
home the next term's report with first in the class. Jews had to be better than everybody else because it would have been a source of shame and embarrassment if they had been the same or, heaven forbid, worst. Jews were supposed to be more honest, more intelligent, more everything than the goyim. (The term goyim is like Pakeha, it refers to everyone who is not what you are.)

Recollections of anti-Semitism suggest that even minor incidents could have a significant and lasting impact. Casual anti-Semitic remarks, probably said as jokes, had left scars. One woman was told by her best friend one day: 'The trouble with you is that you are a bit beige'. This was said with good humour but she has never forgotten it.

A few recalled examples of severe anti-Semitism. One person in the study said that she believed that she had not been chosen to be Head Girl of her school because she was known to be Jewish.

Those with an immigrant background observed that if they were bullied or picked on or discriminated against it was more likely to be because of their foreignness (looking and sounding different from New Zealanders) than because they were Jewish. Fighting back and succeeding in sport (for boys) seemed to be the best way to overcome the hostility and become accepted.

No one mentioned how they had felt when works like Shakespeare's The Merchant of Venice were studied at school. It would not be surprising if some had suffered agonies of embarrassment and resentment in spite of the efforts of some teachers to present Shylock in a more sympathetic light.

The prevailing ignorance about Jews and Judaism has already been referred to. The little knowledge that there was about Jews sometimes focused on the role of Jews in killing Christ. Typically there was little appreciation of the actual historical circumstances. How did Jewish children perceive Jesus and the blame attached to Jews for his crucifixion? Only a few people spoke of this. Jesus seems to have been a puzzle. If Jesus was Jewish, why were the Jews supposed to have killed him? One woman recalled that she had a strong sense that it was somehow 'wrong' to be Jewish because 'you had done something awful to their Jesus'. Another noted: 'One of my problems as a child was with Jesus - whether or not he was something (special) - I had trouble sorting out whether or not we (Jews) were in fact bad - because we had done this awful thing to this man. I remember wanting a pat answer from Mum and Dad'.

Religious instruction and prayers at school had been a mixed experience. There are now Jewish day schools in Auckland and Wellington, but these had not existed while the people in the study were growing up. Some interviewees were sent by their parents to private schools - Presbyterian, Anglican, or Catholic - for the same sorts of reasons that non-Jewish New Zealanders send their children to private school. The religious character of private education was not seen by the parents as a threat to the children's Judaism. In any case, prayers and religious instruction were also a feature of supposedly secular state schools.

How did the people in the study cope with this aspect of their New Zealand schooling? Two issues were raised. The first related to reconciling the religion that was taught and practised at school with the beliefs taught and practised at home. The second concerned the impact on Jewish children of having to make a choice between going into prayers and religious instruction or deliberately putting themselves on the outside.

Only a few interviewees appear to have been troubled by the conflict between what was believed and practised in their homes and what was taught at school. By school age most children understood that Jewishness was confined to the privacy of their homes. The discrepancy in belief between the private and public worlds was not a problem. Many not only participated in the scripture classes, but won prizes. The content of religious instruction did not seem to bother them too much. The mother of one interviewee remembered that her daughter would come home after scripture class and ask: 'do we believe that?' and the mother would reply. 'no we don't'. She recalled that this did not matter to her daughter who would continue to win the scripture prizes. 'It didn't worry her whether we believed it or not:

The worst consequence of prayers and religious instruction from the point of view of Jewish children was that Jews were put into the position of 'being outsiders'. This was the perception of an interviewee who went to Wellington College in the 1920s. Although he made the point that anti-Catholicism was far more prevalent than anti-Semitism while he was at school, he nonetheless thought that Jews being forced to be outside in that way 'savoured of anti-Semitism'.

Another interviewee who went to Wellington College forty years later, in the early 1960s, observed that little had changed. He found it terrifying at first: 'In a school of over one thousand pupils, there were twelve of us. After the prayers at assembly, there was a hush and when they had sung their hymns and said their prayers. there was the entry of the Jews'.

Those children who opted to go into prayers or whose parents made this choice for them, did not escape problems. An interviewee at Wellington College in the fifties recalled 'looking down' on those kids who were known to be Jewish yet chose to go into prayers. They lost the respect of the other Jews because they weren't 'strong enough in their own right'.

For some, the decision to stay out while the others had prayers and religious instruction had been simple. Being Jewish gave you an excuse (cont inued on page 23) 